\title{
EVALUASI KINERJA JALAN JENDRAL AHMAD YANI DEPAN PASAR KOSAMBI BANDUNG
}

\author{
Tan Lie Ing ${ }^{[1]}$, Indra Rachman Efendi ${ }^{[2]}$
}

\begin{abstract}
ABSTRAK
Pergerakan kendaraan dari suatu tempat asal menuju suatu tempat tujuan setiap hari sering kali terganggu akibat adanya aktivitas yang mengapit kedua sisi jalan. Kegiatan pasar pada sisi jalan seringkali menimbulkan gangguan berupa hambatan samping yang berakibat langsung terhadap kinerja jalan. Dalam penelitian ini dilakukan studi kapasitas, kecepatan, derajat kejenuhan dan hambatan samping pada saat pasar tumpah ke jalan dan pada saat kendaraan parkir disamping ruas jalan Jalan Jendral Ahmad Yani Bandung, dengan menggunakan Manual Kapasitas Jalan Indonesia (MKJI) 1997. Survei dilakukan pada hari Selasa tanggal 03 Oktober 2006, pada jam 05:00-09:00. Parameter yang diukur selama survei adalah jumlah kendaraan, waktu tempuh dan hambatan samping. Metode yang digunakan adalah Metode Pos Pengamat Tetap. Volume yang terjadi pada kondisi pasar tumpah ke jalan sebesar 1276,7 smp/jam/2 arah dan volume yang terjadi pada kondisi kendaraan parkir sebesar 2304,8 smp/jam/2 arah. Derajat kejenuhan (DS) adalah 0,32 pada kondisi pasar tumpah ke jalan dan 0,50 pada kondisi kendaraan parkir. Kecepatan tempuh teoritis untuk pasar tumpah ke jalan $35 \mathrm{~km} / \mathrm{jam}$ dan kecepatan tempuh teoritis pada kondisi parkir kendaraan sebesar $36 \mathrm{~km} / \mathrm{jam}$, tetapi kecepatan tempuh hasil survei pada kondisi pasar tumpah ke jalan sebesar 19,36 km/jam dan kecepatan tempuh hasil survei pada kondisi kendaraan parkir sebesar 20,97 km/jam. Aktivitas pasar Kosambi mempengaruhi nilai hambatan samping dan mengakibatkan penurunan kinerja jalan. Pemindahan lokasi pasar yang tumpah ke jalan perlu dilakukan karena kecepatan tempuh kurang dari $25 \mathrm{~km} / \mathrm{jam}$.
\end{abstract}

Kata kunci : Kecepatan tempuh, Derajat kejenuhan, Kapasitas.

\begin{abstract}
Movement of vehicle from one location to other is frequently obstacled because of the activity on both roadside. Activity of market at roadside oftentimes generates trouble in the form of resistance that cause to road and street performance. This research is conducted to study of capacities, speed, degree of saturation and side friction when the road is used for market and the vehicle park at Ahmad Yani Street, Bandung, using MKJI (1997). Survey is done at 05:00-09:00 on Tuesday, October 03, 2006. Measured parameter during surveys is the amount of vehicles, time of journey, and side friction. Method of Post Observer is used. Volume and Degree of saturation (DS) at the time when the road is used for market are $1276.7 \mathrm{smp} /$ hour $/ 2$ directions and 0.32 . Volume and DS when vehicles parked on the road side are $2304.8 \mathrm{smp} /$ hour/2 directions 0.5 . Theoretical Speed when the road used for market and when the vehicle park are $35 \mathrm{~km} /$ hour and $36 \mathrm{~km} /$ hour, respectively. On the other hand, the result of survey speed is $19.36 \mathrm{~km} /$ hour when the road is used for market and $20.97 \mathrm{~km} /$ hour when vehicle park on the side road. Activity at Kosambi market influenced the value of side friction and result decreasing of street performance. The location on the side road is used for market, needs to be move because the speed of journey less than $25 \mathrm{~km} /$ hour.
\end{abstract}

Keywords : Speed of journey, Degree of saturation, Capacity. 


\section{PENDAHULUAN}

\subsection{Latar Belakang}

Bandung sebagai Ibukota Provinsi Jawa Barat, mempunyai banyak aktivitas bisnis, perkantoran dan komersil. Dengan adanya aktivitas-aktivitas tersebut maka diperlukan adanya prasarana jalan yang menghubungkan ke pusat-pusat aktivitas. Pusat aktivitas di Kota Bandung tersebut, antara lain terdapat di daerah kosambi, Jalan Asia Afrika, Jalan Jendral Gatot Subroto dan Jalan Otto Iskandardinata.

Peningkatan jumlah penduduk, jumlah kendaraan dan aktivitas di Kota Bandung menimbulkan masalah sosial dan ekonomi yang sangat bergantung pada transportasi jalan raya. Masalah ini muncul karena adanya ketidakseimbangan antara peningkatan kepemilikan kendaraan dan pertumbuhan prasarana jalan. Masalah-masalah yang akan timbul antara lain adalah kemacetan lalu lintas, peningkatan waktu tempuh, meningkatnya angka kecelakaan dan kerusakan lingkungan hidup, berupa pemborosan bahan bakar, kebisingan dan polusi udara.

Kapasitas efektif ruas jalan yang ada lebih kecil dari kapasitas jalan yang direncanakan akibat adanya hambatan di tepi jalan dan tingkat pertumbuhan kendaraan dan penduduk yang sangat tinggi. Hambatan di tepi jalan tersebut sering kali terkait dengan adanya aktivitas sosial dan ekonomi di tepi jalan, yang menyebabkan kinerja jalan mengalami penurunan.

Jalan Kosambi merupakan penghubung antara daerah perkantoran dan daerah komersil. Setiap hari pada jalan tersebut terdapat aktivitas pasar yang sangat mengganggu kelancaran lalu lintas sehingga kinerja Jalan Jend. Ahmad Yani dipengaruhi oleh adanya aktivitas pasar di jalan tersebut. Dengan demikian, kinerja jalan dari Jalan Jend. Ahmad Yani perlu dievaluasi.

\subsection{Tujuan}

Tujuan penelitian adalah mengevaluasi kinerja jalan Jend. Ahmad Yani di depan pasar Kosambi dengan menentukan besarnya kapasitas, derajat kejenuhan, dan kecepatan, sehingga dapat ditentukan pengaruh aktivitas Pasar Kosambi tersebut terhadap kinerja jalan Jendral Ahmad Yani.

\section{TINJAUAN PUSTAKA}

\subsection{Definisi dan Karakteristik Jalan Perkotaan}

Jalan perkotaan adalah jalan yang terdapat perkembangan secara permanen dan menerus di sepanjang atau hampir seluruh jalan, minimum pada satu sisi jalan, baik berupa 
perkembangan lahan atau bukan. Yang termasuk dalam kelompok jalan perkotaan adalah jalan yang berada didekat pusat perkotaan dengan jumlah penduduk lebih dari 100.000 jiwa. Jalan di daerah perkotaan dengan jumlah penduduk yang kurang dari 100.000 juga dapat digolongkan pada kelompok ini jika perkembangan samping jalan tersebut bersifat permanen dan terus menerus.

Jalan dikelompokkan sesuai fungsi jalan. Fungsi jalan tersebut dikelompokkan sebagai berikut :

a. Jalan Arteri; jalan yang melayani lalu lintas khususnya melayani angkutan jarak jauh dengan kecepatan rata-rata tinggi serta jumlah akses yang dibatasi.

b. Jalan Kolektor; jalan yang melayani lalu lintas terutama terutama melayani angkutan jarak sedang dengan kecepatan rata-rata sedang serta jumlah akses yang masih dibatasi.

c. Jalan Lokal; jalan yang melayani angkutan setempat terutama angkutan jarak pendek dan kecepatan rata-rata rendah serta akses yang tidak dibatasi.

Karakteristik suatu jalan akan mempengaruhi kinerja jalan tersebut. Karakteristik jalan tersebut terdiri atas beberapa hal, yaitu :

1. Geometrik

2. Komposisi arus dan pemisahan arah; volume lalu lintas dipengaruhi komposisi arus lalu lintas, setiap kendaraan yang ada harus dikonversikan menjadi suatu kendaraan standar.

3. Pengaturan lalu lintas, batas kecepatan jarang diberlakukan didaerah perkotaan Indonesia, dan karenanya hanya sedikit berpengaruh pada kecepatan arus bebas.

4. Hambatan samping; banyaknya kegiatan samping jalan di Indonesia sering menimbulkan konflik, hingga menghambat arus lalu lintas.

5. Perilaku pengemudi dan populasi kendaraan; manusia sebagai pengemudi kendaraan merupakan bagian dari arus lalu lintas yaitu sebagai pemakai jalan. Faktor psikologis, fisik pengemudi sangat berpengaruh dalam menghadapi situasi arus lalu lintas yang dihadapi.

Geometrik suatu jalan terdiri dari beberapa unsur fisik dari jalan sebagai berikut :

a. Tipe jalan; berbagai tipe jalan akan menunjukan kinerja berbeda pada pembebanan lalulintas tertentu, misalnya jalan terbagi, jalan tak terbagi, dan jalan satu arah.

b. Lebar jalur; kecepatan arus bebas dan kapasitas meningkat dengan pertambahan lebar jalur lalu-lintas.

c. Bahu/Kereb; kecepatan dan kapasitas jalan akan meningkat bila lebar bahu semakin lebar. Kereb sangat berpengaruh terhadap dampak hambatan samping jalan.

Hambatan samping sangat mempengaruhi lalu lintas. Faktor-faktor yang 
mempengaruhi hambatan samping adalah :

a. Pejalan kaki atau menyebrang sepanjang segmen jalan.

b. Kendaraan berhenti dan parkir.

c. Kendaraan bermotor yang masuk dan keluar ke/dari lahan samping jalan dan jalan sisi.

d. Kendaraan yang bergerak lambat, yaitu sepeda, becak, delman, pedati, traktor, dan sebagainya.

\subsection{Parameter Arus Lalu Lintas}

Berdasarkan MKJI 1997 fungsi utama dari suatu jalan adalah memberikan pelayanan transportasi sehingga pemakai jalan dapat berkendaraan dengan aman dan nyaman. Parameter arus lalu lintas yang merupakan faktor penting dalam perencanaan lalu lintas adalah volume, kecepatan, dan kerapatan lalu lintas.

\subsubsection{Volume (Q)}

Volume adalah jumlah kendaraan yang melewati satu titik pengamatan selama periode waktu tertentu. Volume kendaraan dihitung berdasarkan persamaan :

$$
Q=\frac{N}{T}
$$

dengan :

$Q=$ volume $(\mathrm{kend} / \mathrm{jam})$

$N=$ jumlah kendaraan (kend)

$T=$ waktu pengamatan (jam)

Penggolongan tipe kendaraan untuk jalan dalam kota berdasarkan MKJI 1997 adalah sebagai berikut:

1. Kendaraan ringan / Light Vehicle (LV).

Kendaraan bermotor beroda empat, dengan dua gandar berjarak 2,0-3,0 m (termasuk kendaraan penumpang, opelet, mikro bis, angkot, mikro bis, pick-up, dan truk kecil).

2. Kendaraan berat / Heavy Vehicle (HV).

Kendaraan bermotor dengan jarak as lebih dari 3,50 m, biasanya beroda lebih dari empat, (meliputi : bis, truk dua as, truk tiga as dan truk kombinasi sesuai sistem klasifikasi Bina Marga).

3. Sepeda motor / Motor Cycle (MC)

Kendaraan bermotor dengan dua atau tiga roda (termasuk sepeda motor, kendaraan roda tiga sesuai sistem klasifikasi Bina Marga).

4. Kendaraan tak bermotor / Unmotorised (UM) 
Kendaraan bertenaga manusia atau hewan di atas roda (meliputi sepeda, becak, kereta kuda dan kereta dorong sesuai sistem klasifikasi Bina Marga).

Berbagai jenis kendaraan diekivalensikan ke satuan mobil penumpang dengan menggunakan faktor ekivalensi mobil penumpang (emp), emp adalah faktor yang menunjukkan berbagai tipe kendaraan dibandingkan dengan kendaraan ringan. Nilai emp untuk berbagai jenis tipe kendaraan dapat dilihat pada Tabel 1 dan Tabel 2.

Tabel 1. Ekivalensi Kendaraan Penumpang (emp) untuk Jalan Perkotaan Tak Terbagi

\begin{tabular}{|c|c|c|c|c|}
\hline \multirow{4}{*}{$\begin{array}{c}\text { Tipe jalan } \\
\text { Jalan tak terbagi }\end{array}$} & \multirow{4}{*}{$\begin{array}{l}\text { Arus lalu lintas } \\
\text { total dua arah } \\
\text { (kendaraan/jam) }\end{array}$} & \multicolumn{3}{|c|}{ emp } \\
\hline & & \multirow{3}{*}{ HV } & \multicolumn{2}{|c|}{ MC } \\
\hline & & & \multicolumn{2}{|c|}{ Lebar jalur lalu-lintas Wc (m) } \\
\hline & & & $<6 \mathrm{~m}$ & $>6 \mathrm{~m}$ \\
\hline $\begin{array}{l}\text { Dua-lajur tak-terbagi } \\
\text { (2/2 UD) }\end{array}$ & $\begin{array}{c}0 \\
\geq 1800 \\
\end{array}$ & $\begin{array}{l}1,3 \\
1,2\end{array}$ & $\begin{array}{l}0,50 \\
0,35\end{array}$ & $\begin{array}{l}0,40 \\
0,25\end{array}$ \\
\hline $\begin{array}{l}\text { Empat-lajur tak-terbagi } \\
\text { (4/2 UD) }\end{array}$ & $\begin{array}{c}0 \\
\geq 3700 \\
\end{array}$ & $\begin{array}{l}1,3 \\
1,2 \\
\end{array}$ & \multicolumn{2}{|c|}{$\begin{array}{l}0,40 \\
0,25\end{array}$} \\
\hline
\end{tabular}

Sumber : MKJI 1997

Tabel 2. Ekivalensi Kendaraan Penumpang (emp) untuk Jalan Perkotaan Terbagi dan Satu Arah

\begin{tabular}{|l|c|c|c|}
\hline Tipe jalan: & Arus lalu lintas & \multicolumn{2}{|c|}{ emp } \\
\cline { 3 - 4 } Jalan satu arah dan & $\begin{array}{c}\text { per lajur } \\
\text { kend/jam }\end{array}$ & HV & MC \\
Jalan terbagi & 0 & 1,3 & 0,4 \\
\hline Dua-lajur satu-arah (2/1) & $\geq 1050$ & 1,2 & 0,25 \\
Empat-lajur terbagi (4/2D) & 0 & 1,3 & 0,4 \\
\hline Tiga-lajur satu-arah (3/1) & $\geq 1100$ & 1,2 & 0,25 \\
Enam-lajur terbagi (6/2D) & &
\end{tabular}

Sumber : MKJI 1997

\subsubsection{Kecepatan (V)}

Kecepatan adalah jarak tempuh kendaraan dibagi waktu tempuh.

$$
U=\frac{d}{t}
$$

dengan:

$$
\begin{aligned}
& U=\operatorname{Kecepatan}(\mathrm{km} / \mathrm{jam}) \\
& d=\text { jarak tempuh }(\mathrm{km}) \\
& t=\text { waktu tempuh }(\mathrm{jam})
\end{aligned}
$$

Berbagai macam jenis kecepatan yaitu :

a. Kecepatan bintik (Spot Speed) adalah kecepatan sesaat kendaraan pada titik/lokasi jalan 
tertentu.

b. Kecepatan rata-rata ruang (Space Mean Speed) adalah kecepatan rata-rata kendaraan di sepanjang jalan yang diamati.

$$
U s=\frac{3,6 n d}{\sum_{n=1}^{i} t_{i}}
$$

dengan :

Us $\quad=$ kecepatan rata - rata ruang $(\mathrm{km} / \mathrm{jam})$.

$t \quad=$ waktu perjalanan (detik)

$d \quad=$ jarak (meter)

$n \quad=$ banyaknya kendaraan yang diamati

c. Kecepatan rata-rata waktu (Time Mean Speed) adalah kecepatan rata-rata yang menggambarkan kecepatan rata-rata dari seluruh kendaraan yang melewati satu titik pengamatan pada waktu tertentu.

$$
U t=\frac{\sum_{n=1}^{i} U_{i}}{n}
$$

dengan :

$$
\begin{aligned}
U t & =\text { kecepatan rata }- \text { rata waktu }(\mathrm{km} / \mathrm{jam}) \\
U & =\text { kecepatan kendaraan }(\mathrm{km} / \mathrm{jam}) \\
n & =\text { jumlah kendaraan }
\end{aligned}
$$

d. Kecepatan rata-rata perjalanan (Average Travel Speed) dan kecepatan jalan. Waktu perjalanan adalah total waktu tempuh kendaraan untuk suatu segmen jalan yang ditentukan. Waktu jalan adalah total waktu ketika kendaraan dalam keadaan bergerak (berjalan) untuk menempuh suatu segmen jalan tertentu.

e. Operating Speed dan Percentile Speed

Operating speed adalah kecepatan aman maksimum kendaraan yang dapat ditempuh kendaraan tanpa melampaui kecepatan rencana suatu segmen jalan.

50 percentile speed adalah kecepatan dimana $50 \%$ kendaraan berjalan lebih cepat dan $50 \%$ kendaraan berjalan lebih lambat.

85 percentile speed adalah kecepatan kritis kendaraan dimana kendaraan yang melewati batas ini dianggap berada di luar batas aman.

15 percentile speed adalah batas kecepatan minimum suatu kendaraan dimana kendaraan yang berjalan dengan kecepatan lebih rendah dari ini cenderung menjadi hambatan pada arus lalu lintas dan dapat menyebabkan kecelakaan. 


\subsubsection{Kerapatan (D)}

Kerapatan adalah jumlah kendaraan yang menempati panjang jalan yang diamati dibagi panjang jalan yang diamati tersebut. Kerapatan sulit untuk diukur secara pasti. Kerapatan dapat dihitung berdasarkan kecepatan dan volume. Hubungan antara volume, kecepatan, dan kerapatan adalah sebagai berikut :

$$
\mathrm{D}=\frac{\mathrm{Q}}{\mathrm{U}}
$$

dengan : $\mathrm{D}=$ kerapatan lalu lintas $(\mathrm{kend} / \mathrm{km}), \mathrm{Q}=$ volume lalu lintas $(\mathrm{kend} / \mathrm{jam})$ dan $\mathrm{U}=$ kecepatan lalu lintas $(\mathrm{km} / \mathrm{jam})$

\subsection{Metode Pos Pengamat Tetap}

Pengukuran volume dengan metode pos pengamat tetap dilakukan dengan cara pengamat berada di pos pengamat yang telah di tentukan. Setiap orang dalam pos pengamat menghitung kendaraan yang lewat di depan pos yang telah ditentukan dan mengklasifikasikan jenis kendaraan sesuai dengan klasifikasi kendaraan yang diperlukan.

\subsection{Kinerja Jalan Berdasarkan MKJI 1997}

Tingkat kinerja jalan berdasarkan MKJI 1997 adalah ukuran kuantitatif yang menerangkan kondisi operasional. Nilai kuantitatif dinyatakan dalam kapasitas, derajat kejenuhan, derajat iringan, kecepatan rata - rata, waktu tempuh, tundaan, dan rasio kendaraan berhenti. Ukuran kualitatif yang menerangkan kondisi operasional dalam arus lalu lintas dan persepsi pengemudi tentang kualitas berkendaraan dinyatakan dengan tingkat pelayanan jalan.

\subsubsection{Kapasitas}

Kapasitas didefinisikan sebagai arus maksimum melalui suatu titik di jalan yang dapat dipertahankan per satuan jam pada kondisi tertentu. Untuk jalan dua lajur dua arah, kapasitas ditentukan untuk arus dua arah (kombinasi dua arah), tetapi untuk jalan dengan banyak lajur, arus dipisahkan per arah dan kapasitas di tentukan per lajur. Persamaan dasar untuk menentukan kapasitas adalah sebagai berikut :

$$
\mathrm{C}=\mathrm{C}_{\mathrm{O}} \times \mathrm{FC}_{\mathrm{W}} \times \mathrm{FC}_{\mathrm{SP}} \times \mathrm{FC}_{\mathrm{SF}} \times \mathrm{FC}_{\mathrm{Cs}}
$$

dengan :

$$
\mathrm{C} \quad=\text { Kapasitas }(\mathrm{smp} / \mathrm{jam})
$$




$$
\begin{array}{ll}
\mathrm{C}_{\mathrm{O}} & =\text { Kapasitas dasar (smp/jam) } \\
\mathrm{FC}_{\mathrm{W}} & =\text { Faktor penyesuaian lebar jalan } \\
\mathrm{FC}_{\mathrm{SP}} & =\text { Faktor penyesuaian pemisah arah (hanya untuk jalan tak terbagi) } \\
\mathrm{FC}_{\mathrm{SF}} & =\text { Faktor penyesuaian hambatan samping dan bahu jalan } \\
\mathrm{FC}_{\mathrm{CS}} & =\text { Faktor penyesuaian ukuran kota }
\end{array}
$$

Kapasitas dasar $\left(\mathrm{C}_{0}\right)$ kapasitas segmen jalan pada kondisi geometri, ditentukan berdasarkan tipe jalan sesuai dengan Tabel 3 .

Tabel 3. Kapasitas Dasar (C f $_{0}$ Jalan Perkotaan

\begin{tabular}{|l|c|c|}
\hline \multicolumn{1}{|c|}{ Tipe jalan } & $\begin{array}{c}\text { Kapasitas dasar } \\
\text { (smp/jam) }\end{array}$ & Catatan \\
\hline Empat-lajur terbagi atau Jalan satu-arah & 1650 & Per lajur \\
\hline Empat-lajur tak-terbagi & 1500 & Per lajur \\
\hline Dua-lajur tak-terbagi & 2900 & Total dua arah \\
\hline
\end{tabular}

Sumber : MKJI 1997

Faktor penyesuaian lebar jalan ditentukan berdasarkan lebar jalan efektif yang dapat dilihat pada Tabel 4 .

Tabel 2.4 Faktor Penyesuaian Kapasitas Akibat Lebar Jalan $\left(\right.$ FC $\left._{w}\right)$

\begin{tabular}{|c|c|c|}
\hline Tipe Jalan & $\begin{array}{c}\text { Lebar efektif jalur lalu-lintas (Wc) } \\
\text { (m) }\end{array}$ & FCW \\
\hline Empat-lajur terbagi atau & Per lajur & \\
Jalan satu-arah & 3,00 & 0,92 \\
& 3,25 & 0,96 \\
& 3,50 & 1,00 \\
& 3,75 & 1,04 \\
& 4,00 & 1,08 \\
\hline Empat-lajur tak-terbagi & Per lajur & \\
& 3,00 & 0,91 \\
& 3,25 & 0,95 \\
& 3,50 & 1,00 \\
& 3,75 & 1,05 \\
& 4,00 & 1,09 \\
\hline Dua-lajur tak-terbagi & Total kedua arah & 0,56 \\
& 5 & 0,87 \\
& 6 & 1,00 \\
& 7 & 1,14 \\
& 8 & 1,25 \\
& 9 & 1,29 \\
& 10 & 1,34 \\
\hline
\end{tabular}

Sumber : MKJI 1997 
Faktor penyesuaian pembagian arah jalan didasarkan pada kondisi dan distribusi arus lalu lintas dari kedua arah jalan atau untuk tipe jalan tanpa pembatas median.

Untuk jalan satu arah atau jalan dengan median faktor koreksi pembagian arah jalan adalah 1,0. Faktor penyesuaian pemisah jalan dapat dilihat pada Tabel 5.

Tabel 5. Faktor Penyesuaian Kapasitas Akibat Pembagian Arah (FC $\left.{ }_{\mathrm{SP}}\right)$

\begin{tabular}{|c|l|c|c|c|c|c|}
\hline \multicolumn{2}{|l|}{ Pemisah arah SP (\%-\%) } & $\mathbf{5 0 - 5 0}$ & $\mathbf{5 5 - 4 5}$ & $\mathbf{6 0 - 4 0}$ & $\mathbf{6 5 - 3 5}$ & $\mathbf{7 0 - 3 0}$ \\
\hline \multirow{2}{*}{ FC $_{\text {sP }}$} & Dua-lajur (2/2) & 1,00 & 0,97 & 0,94 & 0,91 & 0,88 \\
\cline { 3 - 7 } & Empat-lajur (4/2) & 1,00 & 0,985 & 0,97 & 0,955 & 0,94 \\
\hline
\end{tabular}

Sumber : MKJI 1997

Faktor penyesuaian kapasitas akibat hambatan samping untuk ruas jalan yang mempunyai kereb didasarkan pada 2 faktor yaitu lebar kereb (Wk) dan kelas hambatan samping.

Nilai faktor penyesuaian kapasitas akibat hambatan samping ini dapat dilihat pada Tabel 6.

Tabel 6. Faktor Penyesuaian Kapasitas Akibat Hambatan Samping $\left(\mathrm{FC}_{\mathrm{SF}}\right)$

\begin{tabular}{|l|c|c|c|c|c|}
\hline Tipe jalan & Kelas hambatan & \multicolumn{3}{|c|}{$\begin{array}{c}\text { Faktor penyesuaian untuk hambatan } \\
\text { samping }\end{array}$} & \multicolumn{4}{|c|}{ Jarak kerb penghalang (Wk) (m) } \\
\cline { 3 - 6 } & & $\leq \mathbf{0 , 5}$ & $\mathbf{1 , 0}$ & $\mathbf{1 , 5}$ & $\geq \mathbf{2 , 0}$ \\
\cline { 3 - 6 } & & 0,95 & 0,97 & 0,99 & 1,01 \\
& & 0,94 & 0,96 & 0,98 & 1,00 \\
& $\mathrm{VL}$ & 0,91 & 0,93 & 0,95 & 0,98 \\
& $\mathrm{~L}$ & 0,86 & 0,89 & 0,92 & 0,95 \\
& $\mathrm{M}$ & 0,81 & 0,85 & 0,88 & 0,92 \\
\hline 4/2 UD & $\mathrm{H}$ & 0,95 & 0,97 & 0,99 & 1,01 \\
& $\mathrm{VH}$ & 0,93 & 0,95 & 0,97 & 1,00 \\
& $\mathrm{VL}$ & 0,90 & 0,92 & 0,95 & 0,97 \\
& $\mathrm{~L}$ & 0,84 & 0,87 & 0,90 & 0,93 \\
& $\mathrm{M}$ & 0,77 & 0,81 & 0,85 & 0,90 \\
\hline 2/2 UD & $\mathrm{H}$ & 0,93 & 0,95 & 0,97 & 0,99 \\
atau Jalan satu-arah & $\mathrm{VH}$ & 0,90 & 0,92 & 0,95 & 0,97 \\
& $\mathrm{VL}$ & 0,86 & 0,88 & 0,91 & 0,94 \\
& $\mathrm{M}$ & 0,78 & 0,81 & 0,84 & 0,88 \\
& $\mathrm{H}$ & 0,68 & 0,72 & 0,77 & 0,82 \\
\hline
\end{tabular}

Sumber : MKJI 1997

Faktor penyesuaian ukuran kota didasarkan pada jumlah penduduk, Faktor penyesuaian ukuran kota dapat dilihat pada Tabel 7. 
Tabel 7. Faktor Penyesuaian Ukuran Kota $\left(\mathrm{FC}_{\mathrm{CS}}\right)$

\begin{tabular}{|c|c|}
\hline Ukuran kota (juta penduduk) & Faktor penyesuaian untuk ukuran kota \\
\hline$<0,1$ & 0,86 \\
\hline $0,1-0,5$ & 0,90 \\
\hline $0,5-1,0$ & 0,94 \\
\hline $1,0-3,0$ & 1,00 \\
\hline$>3,0$ & 1,04 \\
\hline
\end{tabular}

Sumber : MKJI 1997

\subsubsection{Derajat Kejenuhan (DS)}

Derajat kejenuhan (DS) didefinisikan sebagai rasio arus jalan terhadap kapasitas, yang digunakan sebagai faktor utama dalam penentuan tingkat kinerja simpang dan segmen jalan. Nilai DS menunjukkan apakah segmen jalan tersebut mempunyai masalah kapasitas atau tidak. Persamaan dasar untuk menentukan derajat kejenuhan adalah sebagai berikut:

$$
\mathrm{DS}=\frac{\mathrm{Q}}{\mathrm{C}}
$$

dengan :

$$
\begin{aligned}
& \text { DS }=\text { Derajat kejenuhan } \\
& \mathrm{Q}=\text { Arus lalu lintas (smp/jam) } \\
& \mathrm{C}=\text { Kapasitas }(\mathrm{smp} / \mathrm{jam})
\end{aligned}
$$

Derajat kejenuhan digunakan untuk menganalisis perilaku lalu lintas.

\subsubsection{Kecepatan Arus Bebas (FV)}

Kecepatan arus bebas (FV) didefinisikan sebagai kecepatan pada tingkat arus nol yaitu kecepatan yang akan dipilih pengemudi jika mengendarai kendaraan bermotor tanpa dipengaruhi oleh kendaraan bermotor lain di jalan. Persamaan untuk penentuan kecepatan arus bebas mempunyai bentuk umum berikut :

$$
\mathrm{FV}=\left(\mathrm{FV}_{0}+\mathrm{FV}_{\mathrm{w}}\right) \cdot \mathrm{FFV}_{\mathrm{SF}} \cdot \mathrm{FFV}_{\mathrm{CS}}
$$

dengan :

$$
\begin{aligned}
\mathrm{FV}= & \text { Kecepatan arus bebas kendaraan ringan pada kondisi lapangan }(\mathrm{km} / \mathrm{jam}) . \\
\mathrm{FV}_{0}= & \text { Kecepatan arus bebas dasar kendaraan ringan pada jalan yang diamati } \\
& (\mathrm{km} / \mathrm{jam}) . \\
\mathrm{FV}_{\mathrm{W}}= & \text { Penyesuaian kecepatan untuk lebar jalan }(\mathrm{km} / \mathrm{jam}) . \\
\mathrm{FFV}_{\mathrm{SF}}= & \text { Faktor penyesuaian akibat hambatan samping dan lebar bahu. } \\
\mathrm{FFV}_{\mathrm{CS}}= & \text { Faktor penyesuaian ukuran kota }
\end{aligned}
$$


Kecepatan arus bebas ditentukan berdasarkan tipe jalan dan jenis kendaraan sesuai dengan Tabel 8.

Tabel 8. Kecepatan Arus Bebas Dasar untuk Jalan Perkotaan (FV )

\begin{tabular}{|c|c|c|c|c|}
\hline \multirow{2}{*}{$\begin{array}{c}\text { Tipe jalan/ } \\
\text { Tipe alinyemen } \\
\text { (kelas jarak pandang) }\end{array}$} & \multicolumn{4}{|c|}{ Kecepatan arus bebas dasar (FV0) (km/jam) } \\
\hline & $\begin{array}{l}\text { Kendaraan } \\
\text { ringan } \\
(\mathrm{LV})\end{array}$ & $\begin{array}{c}\text { Kendaraan } \\
\text { berat } \\
\text { (HV) }\end{array}$ & $\begin{array}{l}\text { Sepeda } \\
\text { motor } \\
(\mathrm{MC})\end{array}$ & $\begin{array}{c}\text { Semua } \\
\text { Kendaraan } \\
\text { (rata-rata) }\end{array}$ \\
\hline $\begin{array}{l}\text { Enam-lajur terbagi }(6 / 2 \mathrm{D}) \text { atau } \\
\text { Tiga-lajur satu-arah }(3 / 1)\end{array}$ & 61 & 52 & 48 & 57 \\
\hline $\begin{array}{l}\text { Empat-lajur terbagi }(4 / 2 \mathrm{D}) \text { atau } \\
\text { Dua-lajur satu-arah }(3 / 1)\end{array}$ & 57 & 50 & 47 & 55 \\
\hline Empat-lajur tak terbagi (4/2 UD) & 53 & 46 & 43 & 51 \\
\hline Dua-lajur tak-terbagi (2/2 UD) & 44 & 40 & 40 & 42 \\
\hline
\end{tabular}

Sumber : MKJI 1997

Penyesuaian kecepatan arus bebas untuk lebar jalur lalu lintas berdasarkan lebar jalur lalu lintas efektif dan kelas hambatan samping dapat dilihat pada Tabel 9. Lebar lalu lintas efektif diartikan sebagai lebar jalur tempat gerakan lalu lintas setelah dikurangi oleh lebar jalur akibat hambatan samping. Faktor penyesuaian kecepatan arus bebas akibat lebar jalan $\left(\mathrm{FV}_{\mathrm{w}}\right)$ dipengaruhi oleh kelas jarak pandang dan lebar jalur efektif. Tabel 2.9 dapat digunakan untuk jalan empat lajur terbagi.

Tabel 9. Penyesuaian Kecepatan Arus Bebas Untuk Lebar Jalur Lalu-Lintas $\left(\mathrm{FV}_{\mathbf{w}}\right)$

\begin{tabular}{|l|c|c|}
\hline \multicolumn{1}{|c|}{ Tipe Jalan } & $\begin{array}{c}\text { Lebar jalur lalu lintas efektif } \\
\text { jalur lalu-lintas (Wc) } \\
\text { (m) }\end{array}$ & FV \\
\hline Empat-lajur terbagi & Per lajur & -4 \\
atau & 3,00 & -2 \\
Jalan satu arah & 3,25 & 0 \\
& 3,50 & 2 \\
\hline & 3,75 & 4 \\
\hline Empat-lajur tak-terbagi & 4,00 & -4 \\
& Per lajur & -2 \\
& 3,00 & 0 \\
& 3,25 & 2 \\
& 3,50 & 4 \\
\hline Dua-lajur tak-terbagi & 3,75 & \\
& 4,00 & -10 \\
& Total & -3 \\
& 5 & 0 \\
& 6 & 3 \\
& 7 & 4 \\
& 8 & 6 \\
& 9 & 7 \\
\hline
\end{tabular}

Sumber : MKJI 1997 
Faktor penyesuaian kecepatan arus bebas akibat hambatan samping berdasarkan jarak kereb dan penghalang pada trotoar $\left(\mathrm{FFV}_{\mathrm{SF}}\right)$. untuk jalan dengan kereb dapat dilihat pada Tabel 10 .

Tabel 10. Faktor Penyesuaian Kecepatan Arus Bebas Untuk Hambatan Samping dengan Jarak Kerb Penghalang ( FFV $_{\mathrm{SF}}$ )

\begin{tabular}{|c|c|c|c|c|c|}
\hline \multirow[t]{3}{*}{ Tipe jalan } & \multirow[t]{3}{*}{$\begin{array}{l}\text { Kelas hambatan } \\
\text { samping (SFC) }\end{array}$} & \multicolumn{4}{|c|}{$\begin{array}{l}\text { Faktor penyesuaian untuk hambatan samping dan } \\
\text { lebar kereb penghalang }\left(\mathrm{FFV}_{\mathrm{SF}}\right)\end{array}$} \\
\hline & & \multicolumn{4}{|c|}{ Jarak: kereb penghalang $\left(\mathrm{W}_{\mathrm{k}}\right)(\mathrm{m})$} \\
\hline & & $<0,5$ & 1,0 & 1,5 & $>2,0$ \\
\hline $\begin{array}{l}\text { Empat-lajur terbagi } \\
4 / 2 \mathrm{D}\end{array}$ & $\begin{array}{l}\text { Sangat rendah } \\
\text { Rendah } \\
\text { Sedang } \\
\text { Tinggi } \\
\text { Sangat tinggi } \\
\end{array}$ & $\begin{array}{l}1,00 \\
0,97 \\
0,93 \\
0,87 \\
0,81 \\
\end{array}$ & $\begin{array}{l}1,01 \\
0,98 \\
0,95 \\
0,90 \\
0,85\end{array}$ & $\begin{array}{l}1,01 \\
0,99 \\
0,97 \\
0,93 \\
0,88 \\
\end{array}$ & $\begin{array}{l}1,02 \\
1,00 \\
0,99 \\
0,96 \\
0,92 \\
\end{array}$ \\
\hline $\begin{array}{l}\text { Empat-lajur tak- } \\
\text { terbagi } \\
4 / 2 \text { UD }\end{array}$ & $\begin{array}{c}\text { Sangat rendah } \\
\text { Rendah } \\
\text { Sedang }\end{array}$ & $\begin{array}{l}0,96 \\
0,91\end{array}$ & $\begin{array}{l}0,98 \\
0,93\end{array}$ & $\begin{array}{l}0,99 \\
0,96\end{array}$ & $\begin{array}{l}1,02 \\
1,00 \\
0,98\end{array}$ \\
\hline & $\begin{array}{c}\text { Tinggi } \\
\text { Sangat tinggi }\end{array}$ & $\begin{array}{l}0,84 \\
0,77\end{array}$ & $\begin{array}{l}0,87 \\
0,81\end{array}$ & $\begin{array}{l}0,90 \\
0,85\end{array}$ & $\begin{array}{l}0,94 \\
0,90\end{array}$ \\
\hline $\begin{array}{l}\text { Dua-lajur tak- terbagi } \\
2 / 2 \text { UD atau } \\
\text { Jalan satu arah }\end{array}$ & $\begin{array}{l}\text { Sangat rendah } \\
\text { Rendah } \\
\text { Sedang } \\
\text { Tinggi } \\
\text { Sangat tinggi }\end{array}$ & $\begin{array}{l}0,98 \\
0,93 \\
0,87 \\
0,78 \\
0,68\end{array}$ & $\begin{array}{l}0,99 \\
0,95 \\
0,89 \\
0,81 \\
0,72\end{array}$ & $\begin{array}{l}0,99 \\
0,96 \\
0,92 \\
0,84 \\
0,77\end{array}$ & $\begin{array}{l}, 00 \\
0,98 \\
0,95 \\
0,88 \\
0,82\end{array}$ \\
\hline
\end{tabular}

\section{Sumber : MKJI 1997}

Nilai faktor penyesuaian untuk pengaruh ukuran kota pada kecepatan arus bebas kendaraan $\left(\mathrm{FFV}_{\mathrm{CS}}\right)$ dapat dilihat pada Tabel 11.

Tabel 11. Faktor Penyesuaian Kecepatan Arus Bebas untuk Ukuran Kota $\left(\mathrm{FFV}_{\mathrm{CS}}\right)$

\begin{tabular}{|c|c|}
\hline Ukuran kota (Juta Penduduk) & Faktor penyesuaian untuk ukuran kota \\
\hline$<0,1$ & 0,90 \\
$0,1-0,5$ & 0,93 \\
$0,5-1,0$ & 0,95 \\
$1,0-3,0$ & 1,00 \\
$>3,0$ & 1,03 \\
\hline
\end{tabular}

Sumber : MKJI 1997

\subsubsection{Kecepatan Tempuh}

MKJI 1997 menggunakan kecepatan tempuh sebagai ukuran utama kinerja segmen jalan, karena mudah dimengerti dan diukur, dan merupakan masukan yang penting untuk biaya pemakai jalan dalam analisis ekonomi. Kecepatan tempuh ditentukan dengan 
menggunakan grafik pada Gambar 1.

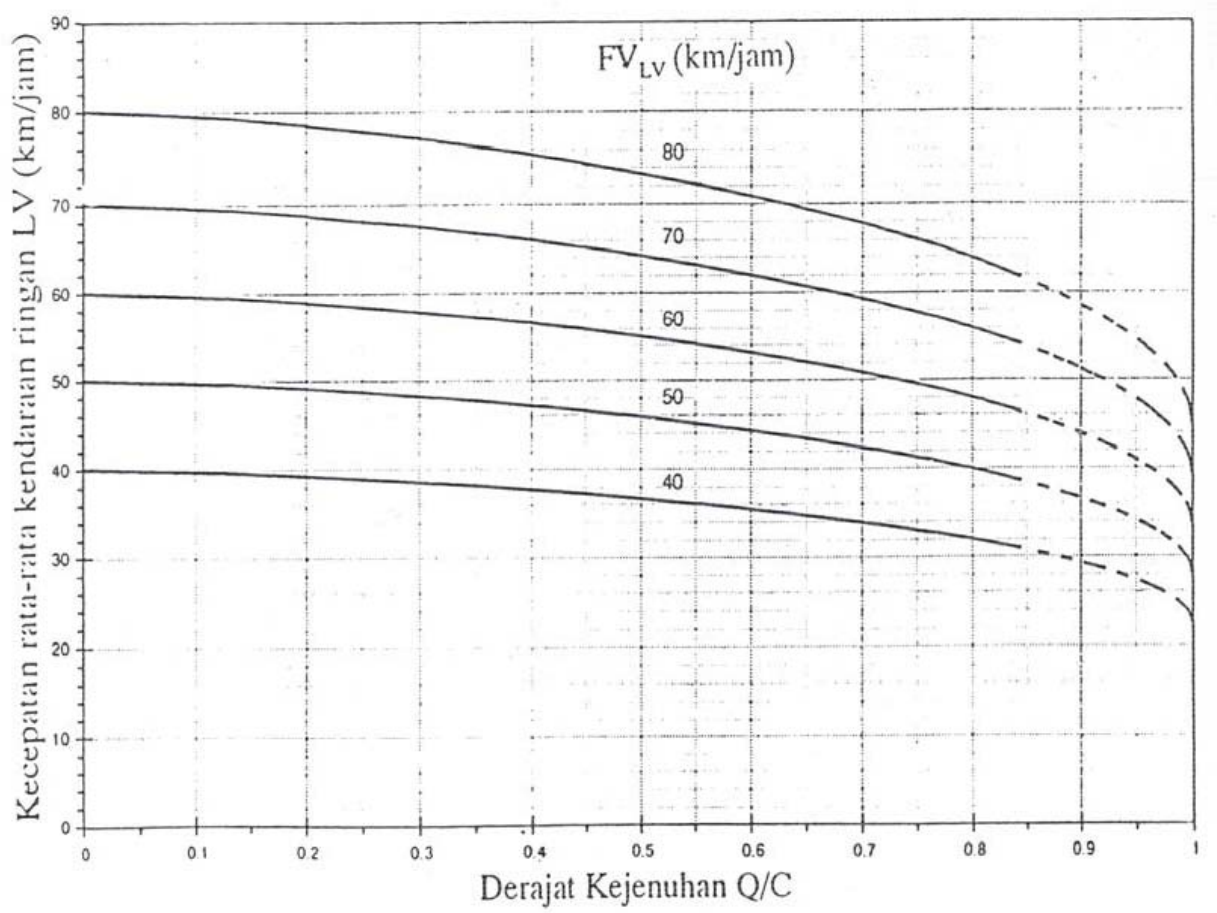

Gambar 1. Kecepatan sebagai fungsi DS untuk jalan banyak lajur dan satu Arah

\subsubsection{Hambatan Samping}

Hambatan samping, yaitu aktivitas samping jalan yang dapat menimbulkan konflik dan berpengaruh terhadap pergerakan arus lalu lintas serta menurunkan kinerja jalan. Adapun tipe kejadian hambatan samping, adalah :

1. Jumlah pejalan kaki berjalan atau menyeberangsepanjang segmen jalan.

2. Jumlah kendaraan berhenti dan parkir.

3. Jumlah kendaraan bermotor yang masuk dan keluar dari lahan samping jalan dan jalan samping.

4. Arus kendaraan lambat, yaitu arus total (kend/ jam) sepeda, becak, delman, pedati, traktor dan sebagainya.

Tingkat hambatan samping dikelompokkan ke dalam lima kelas dari yang rendah sampai sangat tinggi sebagai fungsi dari frekuensi kejadian hambatan samping sepanjang segmen jalan yang diamati. Menurut MKJI 1997 kelas hambatan samping dikelompokkan seperti yang ada pada Tabel 12 . 
Tabel 12. Kelas Hambatan Samping

\begin{tabular}{|c|c|c|c|}
\hline $\begin{array}{l}\text { Kelas } \\
\text { samping } \\
(\mathrm{SFC})\end{array}$ & Kode & $\begin{array}{c}\text { Jumlah berbobot } \\
\text { kejadian per } \\
200 \text { meter per } \\
\text { (dua sisi) }\end{array}$ & Kondisi Khusus \\
\hline $\begin{array}{l}\text { Sangat rendah } \\
\text { Rendah }\end{array}$ & $\begin{array}{l}\text { VL } \\
\mathrm{L}\end{array}$ & $\begin{array}{l}<100 \\
100-299\end{array}$ & $\begin{array}{l}\text { Daerah pemukiman ; jalan dengan jalan samping } \\
\text { Daerah pemukiman ; beberapa kendaraan umum } \\
\text { dsb }\end{array}$ \\
\hline $\begin{array}{l}\text { Sedang } \\
\text { Tinggi } \\
\text { Sangat tinggi }\end{array}$ & $\begin{array}{l}\mathrm{M} \\
\mathrm{H} \\
\mathrm{VH}\end{array}$ & $\begin{array}{l}300-499 \\
500-899 \\
>900\end{array}$ & $\begin{array}{l}\text { Daerah industri, beberapa toko di sisi jalan } \\
\text { Daerah komersial, aktivitas disisi jalan tinggi } \\
\text { Daerah komersil dengan aktivitas pasar di } \\
\text { jalan }\end{array}$ \\
\hline
\end{tabular}

Sumber : MKJI 1997

\section{METODOLOGI PENELITIAN}

\subsection{Lokasi Survei}

Lokasi yang dipilih untuk penelitian yaitu ruas Jalan Jend. Ahmad Yani. Peta lokasi penelitian dapat dilihat pada Gambar 2 dan denah lokasi penelitian dapat dilihat pada Gambar 3 .

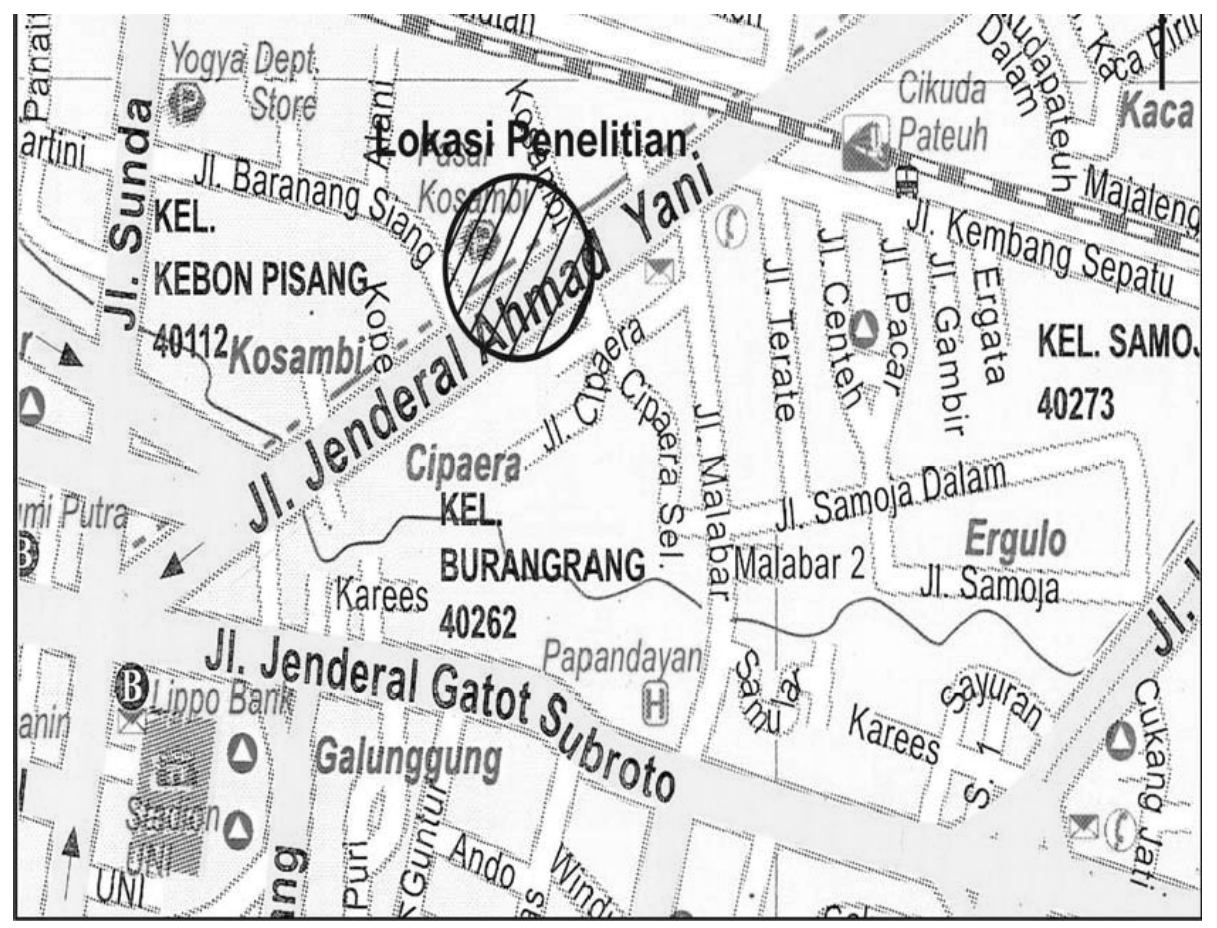

Gambar 2. Peta Lokasi Penelitian 


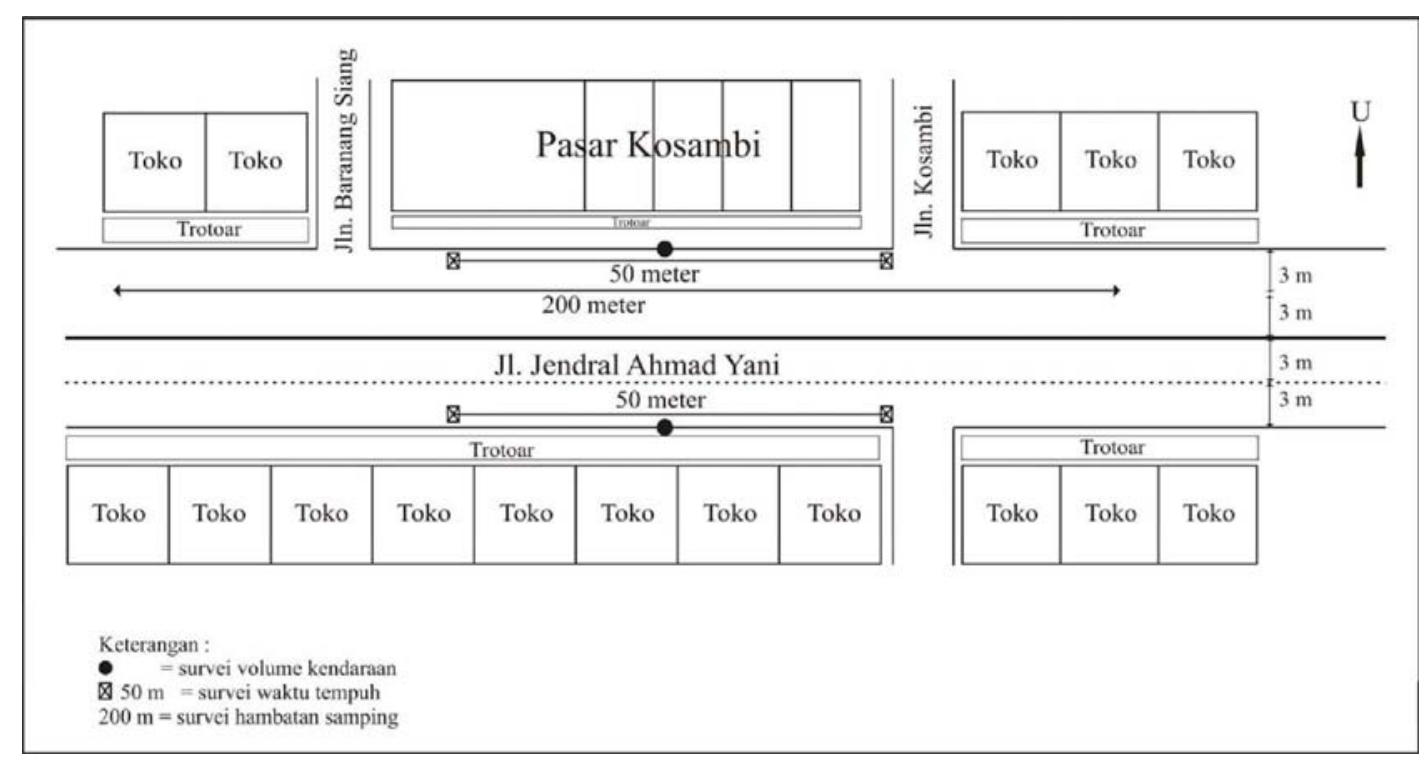

Gambar 3. Denah Lokasi Penelitian

\subsection{Pengumpulan Data}

Pengumpulan data di lapangan harus dilakukan dengan cara seteliti mungkin agar diperoleh data akurat dan memenuhi. Data yang diukur adalah data geometrik jalan dari ruas jalan yang digunakan sebagai lokasi penelitian. Survei yang dilakukan adalah survei jumlah kendaraan berdasarkan klasifikasi kendaraan, survei waktu tempuh dan survei hambatan samping.

\subsubsection{Survei Volume lalu lintas}

Survei dilakukan dengan cara menghitung langsung jumlah kendaraan yang melewati titik pengamatan dengan menggunakan counter. Survei dilakukan oleh dua surveyor pada titik pengamatan untuk setiap arah lalu lintas, dimana setiap surveyor akan menghitung tiap jenis kendaraan berdasarkan klasifikasi kendaraan. Jenis kendaraan yang diamati adalah: sepeda motor(MC), kendaraan ringan(LV) dan kendaraan berat(HV)

\subsubsection{Survei Waktu Tempuh}

Survei dilakukan dengan cara menghitung waktu tempuh dari kendaraan yang bergerak dengan menggunakan stopwatch. Survei dilakukan oleh dua surveyor pada satu lajur, Surveyor pertama bertugas sebagai pencatat waktu yaitu dimulai pada saat bagian depan dari kendaraan yang diamati berada di titik pengamatan sampai kendaraan tersebut bergerak mencapai jarak 50 meter, sedangkan surveyor kedua bertugas memberi tanda apabila kendaraan yang diamati telah berada sejarak 50 meter. 


\subsubsection{Survei Hambatan Samping}

Survei hambatan samping dilakukan dengan cara menghitung langsung setiap tipe kejadian per jam per 200 meter pada lajur jalan yang diamati. Tipe kejadian digolongkan menjadi sebagai berikut :

1. Jumlah pejalan kaki berjalan atau menyeberang sepanjang segmen jalan.

2. Jumlah kendaraan berhenti atau parkir.

3. Jumlah kendaraan bermotor yang masuk dan keluar dari lahan samping jalan.

4. Arus kendaraan yang bergerak lambat, yaitu arus total (kend/jam) dari sepeda, becak, pedati, traktor dan sebagainya.

Survei dilakukan oleh 4 surveyor pada lajur jalan per 200 meter, dimana setiap surveyor menghitung semua tipe kejadian per 200 meter per jam.

\section{PENGOLAHAN DAN ANALISIS DATA}

\subsection{Data Geometrik Jalan}

Berdasarkan hasil pengukuran dan pengamatan secara visual di lapangan yang dilakukan terhadap geometri jalan, diambil potongan melintang jalan pada segmen dimana jalan diamati dan mewakili karakteristik segmen jalan. Posisi potongan melintang pada segmen ditunjukkan pada Gambar 4, Gambar 5, dan Gambar 6.

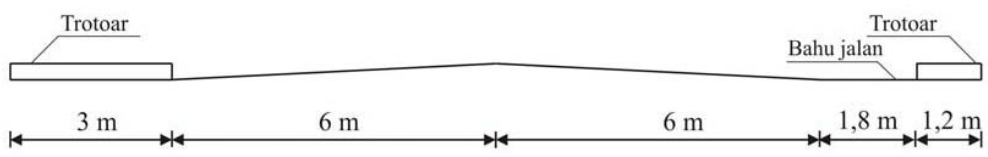

Gambar 4. Penampang Melintang Segmen Jalan

Trotoar

Gambar 5. Penampang Melintang Segmen Jalan Pada Saat Pasar Tumpah ke Jalan

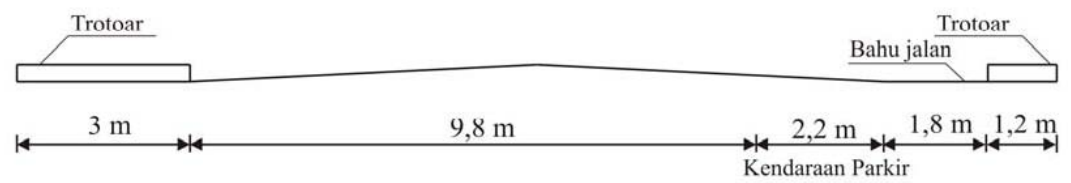

Gambar 6. Penampang Melintang Segmen Jalan Pada Saat Pasar tidak Tumpah ke Jalan (kend. parkir) 


\subsection{Perhitungan Volume Lalu Lintas}

Tabel 13 menunjukkan hasil perhitungan volume lalu lintas total dua arah untuk kondisi pasar tumpah ke jalan per jam dan Tabel 14 menunjukkan hasil perhitungan volume lalu lintas total dua arah untuk kondisi kendaraan parkir per jam.

Contoh perhitungan lalu lintas pada hari Selasa tanggal 03 Oktober 2006 arah Timur - Barat.

Volume lalu lintas (Q1) jam 07:00 - 07:15 = 266,2 smp/15 menit/arah

Volume lalu lintas (Q2) jam 07:15 - 07:30 $=360,0 \mathrm{smp} / 15$ menit/arah

Volume lalu lintas (Q3) jam 07:30 - 07:45 = 361,2 smp/15 menit/arah

Volume lalu lintas (Q4) jam 07:45 - 08:00 $=401,4 \mathrm{smp} / 15$ menit/arah

Volume lalu lintas (Q) pada tanggal 31 Mei 2006 jam 07:00 - 08:00 WIB

$$
\begin{aligned}
\mathrm{Q} & =\mathrm{Q} 1+\mathrm{Q} 2+\mathrm{Q} 3+\mathrm{Q} 4 \\
& =266,2+360,0+361,2+401,4 \\
& =1388,8 \mathrm{smp} / \mathrm{jam} / \mathrm{arah}
\end{aligned}
$$

Tabel 13. Hasil Perhitungan Volume Lalu Lintas Kondisi Pasar Tumpah ke Jalan

\begin{tabular}{|c|c|c|c|}
\hline \multirow{2}{*}{ Waktu Pengamatan } & \multicolumn{2}{|c|}{ Volume Total (smp/jam) } & \multirow{2}{*}{$\begin{array}{c}\text { Total } \\
\text { (smp/jam) }\end{array}$} \\
\cline { 2 - 3 } & Barat - Timur & Timur - Barat & \\
\hline $05: 00-06: 00$ & 248,3 & 291,0 & 539,3 \\
\hline $05: 15-06: 15$ & 301,0 & 356,1 & 657,1 \\
\hline $05: 30-06: 30$ & 479,3 & 490,6 & 969,9 \\
\hline $05: 45-06: 45$ & 408,5 & 649,8 & 1058,3 \\
\hline $06: 00-07: 00$ & 506,0 & 770,7 & 1276,7 \\
\hline
\end{tabular}

Tabel 14. Hasil Perhitungan Volume Lalu Lintas kondisi Kendaraan Parkir

\begin{tabular}{|c|c|c|c|}
\hline Waktu Pengamatan & \multicolumn{2}{|c|}{ Volume Total (smp/jam) } & $\begin{array}{c}\text { Total } \\
\text { (smp/jam) }\end{array}$ \\
\cline { 2 - 4 } & Barat - Timur & Timur - Barat & \\
\hline $07: 00-08: 00$ & 778,9 & 1388,8 & 2167,7 \\
\hline $07: 15-08: 15$ & 809,5 & 1495,3 & 2304,8 \\
\hline $07: 30-08: 30$ & 787,4 & 1481,5 & 2268,9 \\
\hline $07: 45-08: 45$ & 732,9 & 1451,1 & 2184,0 \\
\hline $08: 00-09: 00$ & 655,3 & 1379,3 & 2034,6 \\
\hline
\end{tabular}

\subsection{Perhitungan kecepatan rata-rata ruang}

Hasil perhitungan kecepatan rata-rata ruang (Us) untuk 2 arah dapat dilihat pada Tabel 15 untuk kondisi pasar tumpah ke jalan dan Tabel 16 untuk kondisi kendaraan parkir. Contoh perhitungan dilakukan untuk data waktu tempuh tanggal 03 Oktober 2006 jam 07:00 - 08:00 WIB untuk kendaraan ringan arah Barat - Timur. 
Jumlah kendaraan yang diamati $(n)=20$ kendaraan

Jarak pengamatan $(\mathrm{d}) \quad=50$ meter

Waktu tempuh seluruh kendaraan yang diamati $(\Sigma \mathrm{t})=178,88$ detik

Kecepatan rata-rata ruang $(\mathrm{Us}) \quad=\frac{3,6 \mathrm{nd}}{\sum_{\mathrm{n}=1}^{\mathrm{i}} \mathrm{t}_{\mathrm{i}}}=\frac{3,6 \times 20 \times 50}{178.88}=20.13 \mathrm{~km} / \mathrm{jam}$

Tabel 15. Kecepatan Lalu lintas Pada Saat Pasar Tumpah Kejalan

\begin{tabular}{|c|c|c|c|}
\hline \multirow{2}{*}{ Waktu } & Us (km/jam) & Us (km/jam) & Us Rata-rata \\
\cline { 2 - 4 } & Barat - Timur & Timur - Barat & $\mathbf{( k m / j a m ) ~}$ \\
\hline $05.00-06.00$ & 20,20 & 17,82 & 19,01 \\
\hline $06.00-07.00$ & 20,66 & 18,74 & 19,70 \\
\hline \multicolumn{3}{|c|}{ Rata-rata } & $\mathbf{1 9 , 3 6}$ \\
\hline
\end{tabular}

Tabel 16. Kecepatan Lalu lintas Pada Saat Pasar tidak Tumpah Kejalan (Kendaraan Parkir di Samping Jalan)

\begin{tabular}{|c|c|c|c|}
\hline \multirow{2}{*}{ Waktu } & Us (km/jam) & Us (km/jam) & Us Rata-rata \\
\cline { 2 - 4 } & Barat - Timur & Timur - Barat & $\mathbf{( k m / j a m ) ~}$ \\
\hline $07.00-08.00$ & 18,86 & 21,83 & 20,35 \\
\hline $08.00-09.00$ & 20,44 & 22,73 & 21,59 \\
\hline \multicolumn{3}{|c|}{ Rata-rata } & $\mathbf{2 0 , 9 7}$ \\
\hline
\end{tabular}

\subsection{Perhitungan Kapasitas Jalan}

Dengan menggunakan persamaan kapasitas jalan dapat dihitung kapasitas jalan untuk kondisi ideal, kondisi pasar tumpah dan kondisi pasar tidak tumpah (kendaraan parkir). Nilai kapasitas jalan dapat dilihat pada Tabel 17.

Tabel 17. Nilai Kapasitas (C)

\begin{tabular}{|c|c|c|c|c|c|c|}
\hline Kondisi & $C_{0}$ & FC $_{w}$ & $\mathrm{FC}_{\mathrm{SP}}$ & $\mathrm{FC}_{\mathrm{SF}}$ & FC $_{\text {CS }}$ & $\begin{array}{c}C \\
\text { (smp/jam) }\end{array}$ \\
\hline Ideal & 6000 & 0,91 & 1,00 & 1,00 & 1,00 & 5460 \\
\hline Pasar Tumpah & 6000 & 0,73 & 1,00 & 0,90 & 1,00 & 3942 \\
\hline Kendaraan Parkir & 6000 & 0,826 & 1,00 & 0,93 & 1,00 & 4609,08 \\
\hline
\end{tabular}

\subsection{Perhitungan Derajat Kejenuhan (DS)}

Nilai derajat kejenuhan dihitung sebagai rasio antara arus terhadap kapasitas. Nilai derajat kejenuhan (DS) terdapat pada Tabel 18. 
Tabel 18. Nilai Derajat Kejenuhan (Ds)

\begin{tabular}{|c|c|c|c|}
\hline \multirow{2}{*}{ Kondisi } & Volume & $\begin{array}{c}\text { Kapasitas } \\
\text { (smp/jam/per arah) }\end{array}$ & $\begin{array}{c}\text { Derajat } \\
\text { Kejenuhan }\end{array}$ \\
\cline { 2 - 2 } & (smp/jam/2 arah) & 5460 & 0,37 \\
\hline Ideal & 2034,6 & 3942 & 0,32 \\
\hline Pasar Tumpah & 1276,7 & 4609,08 & 0,50 \\
\hline Kendaraan Parkir & 2304,8 & & \\
\hline
\end{tabular}

\subsection{Kecepatan Arus Bebas}

Nilai kecepatan arus bebas dapat dilihat pada Tabel 19.

Tabel 19. Nilai Kecepatan Arus Bebas (FV)

\begin{tabular}{|c|c|c|c|c|c|}
\hline Kondisi & $\mathbf{F V}_{\mathbf{0}}$ & $\begin{array}{c}\mathbf{F V}_{\mathbf{w}} \\
(\mathbf{k m} / \mathbf{j a m})\end{array}$ & $\begin{array}{c}\text { FFV } \\
\text { SF }\end{array}$ & $\begin{array}{c}\text { FFV } \\
\text { Cs }\end{array}$ & $\begin{array}{c}\text { FV } \\
\mathbf{( k m} / \mathbf{j a m})\end{array}$ \\
\hline Ideal & 51 & -4 & 1,03 & 1 & 48,41 \\
\hline Pasar Tumpah & 51 & -13 & 0,95 & 1 & 36,10 \\
\hline Parkir Kendaraan & 51 & $-10,4$ & 0,98 & 1 & 39,79 \\
\hline
\end{tabular}

Nilai kecepatan tempuh dapat dilihat pada Tabel 20.

Tabel 20. Nilai Kecepatan Tempuh (km/jam)

\begin{tabular}{|c|c|c|c|}
\hline Kondisi & DS & FV & $\begin{array}{c}\text { Kecepatan Tempuh } \\
(\mathbf{k m} / \mathbf{j a m})\end{array}$ \\
\hline Pasar Tumpah & 0,32 & 36,10 & 35 \\
\hline Parkir kendaraan & 0,50 & 39,79 & 36 \\
\hline
\end{tabular}

\subsection{Hambatan Samping}

Dengan mempergunakan Tabel Penentuan Kelas Hambatan Samping diperoleh kelas hambatan samping setiap jam dapat dilihat pada Tabel 21.

Tabel 21. Kelas Hambatan Samping

\begin{tabular}{|c|c|}
\hline Waktu & Kelas Hambatan Samping \\
\hline 05:00-06:00 & Sangat Tinggi \\
\hline 06:00-07:00 & Sangat Tinggi \\
\hline 07:00-08:00 & Tinggi \\
\hline 08:00-09:00 & Sedang \\
\hline
\end{tabular}

\subsection{Analisis Data}

Volume yang terjadi pada kondisi pasar tumpah ke jalan sebesar 1276,7 smp/jam/2 arah dan volume yang terjadi pada kondisi kendaraan parkir sebesar 2304,8 smp/jam/2 arah. 
Derajat kejenuhan (DS) adalah 0,32 pada kondisi pasar tumpah ke jalan dan 0,50 pada kondisi parkir kendaraan lebih kecil dari batas maksimum operasional sebesar 0,8. Penurunan volume terjadi akibat adanya aktivitas pasar tumpah ke jalan sebesar 1028,1 smp/jam/2 arah, hal ini juga mengakibatkan terjadinya perubahan nilai hambatan samping dari sedang ke sangat tinggi.

Pada kondisi pasar tumpah ke jalan kecepatan tempuh teoritis berdasarkan MKJI 1997 untuk pasar tumpah ke jalan 35 km/jam dan Kecepatan tempuh teoritis pada kondisi kendaraan parkir sebesar $36 \mathrm{~km} / \mathrm{jam}$. Kecepatan tempuh hasil survei pada kondisi pasar tumpah ke jalan sebesar 19,36 km/jam dan kecepatan tempuh hasil survei pada kondisi parkir kendaraan sebesar 20,97 km/jam. Jadi kecepatan tempuh teoritis lebih besar dari kecepatan tempuh survei, hal ini disebabkan pada saat survei kendaraan mengalami penurunan kecepatan karena adanya aktivitas pasar tumpah ke jalan. Pemindahan lokasi pasar yang tumpah ke jalan perlu dilakukan karena kecepatannya kurang dari $25 \mathrm{~km} / \mathrm{jam}$.

\section{KESIMPULAN}

Dari hasil pengamatan dan analisis data, dapat diambil kesimpulan sebagai berikut :

1. Volume yang terjadi pada kondisi pasar tumpah ke jalan sebesar $1276,7 \mathrm{smp} / \mathrm{jam} / 2$ arah dan volume yang terjadi pada kondisi kendaraan parkir sebesar 2304,8 smp/jam/2 arah, penurunan volume yang terjadi sebesar 1028,1 smp/jam/2 arah.

2. Penurunan kecepatan terjadi karena adanya aktivitas pasar tumpah ke jalan sehingga pemindahan lokasi pasar yang tumpah ke jalan perlu dilakukan karena kecepatannya kurang dari $25 \mathrm{~km} / \mathrm{jam}$.

3. Berdasarkan Derajat kejenuhan (DS) yang terjadi lebih kecil dari batas maksimum operasional sebesar 0,8 , maka tidak perlu dilakukan perbaikan, misalnya pelebaran jalan karena kapasitas yang ada untuk saat ini mencukupi untuk volume kendaraan yang lewat ke jalan Jendral Ahmad Yani.

\section{DAFTAR PUSTAKA}

1. Alik Ansyori Alamsyah, Rekayasa Jalan Raya, Penerbitan Universitas Muhammadiyah Malang.

2. Deni Dermawan Lubis (2006), Pengaruh Hambatan Samping TerhadapKinerja Jalan Pada Ruas Jalan Sayati Kabupaten Bandung, Fakultas Teknik, Jurusan Teknik Sipil, Universitas Kristen Maranatha, Bandung. 
3. Direktorat Jendral Bina Marga (1997), Manual Kapasitas Jalan Indonesia (MKJI), Sweroad dan PT. Bina Karya, Jakarta.

4. Hartanto, Budi (1985), Karakteristik dan Studi Lalu Lintas, Fakultas Teknik, Jurusan Teknik Sipil, Universitas Kristen Maranatha, Bandung.

5. Morlok,E. K. (1988), Pengantar Teknik dan Perencanaan Transportasi, Erlangga, Jakarta.

6. , (1982), Transportation and Traffic Engineering Handbook Second Edition, Intitute Of Transportation Engineerings, Prentice Hall, London.

[1] Tan Lie Ing, ST., MT., Dosen Tetap, Jurusan Teknik Sipil Universitas Kristen Maranatha.

[2] Indra Rachman Efendi, ST., Alumnus Jurusan Teknik Sipil Universitas Kristen Maranatha. 